\title{
THE MORPHOLOGY AND ONTOGENETIC OF TAREBIA GRANIFERA (LAMARCK, 1822) F ROM INDONESIA (GASTROPODA: CERITHIOIDEA: THIARIDAE)
}

\author{
Nur Rohmatin Isnaningsih* ${ }^{1,2}$, Adi Basukriadi ${ }^{1}$ and Ristiyanti Marsetiyowati Marwoto ${ }^{2}$ \\ ${ }^{1}$ Department of Biology, Faculty of Mathematics and Natural Sciences, University of Indonesia \\ ${ }^{2}$ Zoology Division (Museum Zoologicum Bogoriense), Research Center for Biology, Indonesian Institute of Sciences, \\ Jl. Raya Jakarta-Bogor Km 46, Cibinong, Bogor 16911, Indonesia \\ *Corresponding author: ish_naningsih@yahoo.com
}

Received: 14 November 2016; Accepted: 2 November 2017

\begin{abstract}
The freshwater gastropod Tarebia H. Adams \& A. Adams, 1854, are found in rivers, lakes, and other limnetic habitats. In Indonesia, Tarebia granifera (Lamarck, 1822) is the only species within the genus that has a wide distribution. The systematics and identity of this species are still doubtful due to high variation in shell morphology, especially shell height and ornamentation or sculpture of shell. To determine the identity of T. granifera from Lombok, Banten, and Maros, ontogenetic studies have been conducted. The results showed that $T$. granifera from Lombok produce the highest number of embryonic shells. The number of progeny in the brood pouch from a single individual of $T$. granifera can vary between 9 to 203 embryonic shells which are found in various stages of $0.22 \mathrm{~mm}$ to about $5 \mathrm{~mm}$ in size inside the brood pouch.
\end{abstract}

Key words: embryonic shell, ontogeny, subhaemocoelic brood pouch, Tarebia granifera, Thiaridae

\section{INTRODUCTION}

Tarebia granifera (Lamarck, 1822) (Thiaridae) occurs in freshwater bodies, in lotic as well as lentic habitats. This species belongs to benthic fauna and lives attached to different kinds of substrate or on the banks of aquatic habitats. Besides living in natural aquatic habitats, T. granifera is also found in artificial water bodies such as reservoirs and irrigation channels. This species is able to live in temperatures ranging between $6-38^{\circ} \mathrm{C}$ (Appleton et al. 2009). Tarebia granifera is resistant to turbidity and pollution and it tolerates a small degree of salinity (Benthem-Jutting 1956, Kartayev et al. 2009). The spreading of $T$. granifera occurs actively by its own movement and also passively by being carried away by birds or water plants (Appleton et al. 2009).

Tarebia granifera was first described by Lamarck (1816) without any locality given (Cowie 1995). The distribution of T. granifera includes India, Malay Archipelago, Philippines, Taiwan, Japan, and various Pacific islands (Abbot 1952, Benthem-Jutting 1956). Nowadays, this snail is widespread and has become an invasive species at many locations around the world (Appleton et al. 2009). In 1947, T. granifera has been introduced to Florida, US. In 1999, this species was reported from South Africa, and in the same year, it has also been reported to occur in Cuba and small islands in the Caribbean, i.e. Saint Lucia, Martinique (Morrison 1954, Pointier 1998, Appleton \& 
Nadasan 2002). The spreading outside of the natural distribution is attributed through the aquarium and ornamental trades.

In Indonesia, T. granifera fossils were found from the upper layers of the Pliocene in Central and East Java (Benthem-Jutting 1937). This species was reported to occur in Sumatra, from Danau Laut Tawar, Danau Singkarak, Danau Di Atas, Danau Di Bawah, Langkat River and Asahan River (Rensch 1934, Benthem-Jutting 1959). Meanwhile, in Java, T. granifera was found widely distributed from West to East Java, among others from the Ciliwung river, Sukabumi, Cisolok, Cianjur, Pekalongan, Kebumen, Rembang, the Brantas River, Kali Mas and many other locations (Benthem-Jutting 1956). This species is also reported from Bali, Lombok and eastern part of Indonesia like Manado, Ternate, Aru, Waigeo and Raja Ampat Islands, Sorong and Uriami River in Manokwari (Rensch 1932, Benthem-Jutting 1959, 1963).

Specimens from various locations in Indonesia were identified as T. granifera, but the shell morphology showed that there was a high degree of variation. So far morphological characters can be used to distinguish species within the genus Tarebia. However, anatomical characters are also important and required to support the validity and species identity. According to Wagner (2001), shell morphology was strongly influenced by environmental conditions or habitats hence it became easily changed. On the other hand, soft body (anatomical) characters represent the basic adaptation of behaviour that was more stable.

The anatomical characters of reproductive organs can be used to determine the identity of thiarid species. It was shown that characters of the reproductive organs and embryonic shells are more informative at the level of genera (Abbott 1952, Glaubrecht 1999). The structure and form of the reproductive organs as well as ontogeny (embryonic development) can vary inside a genus (interspecies) or even within species (intraspecies).

To assure the validity of Indonesian $T$. granifera status and identity, a comprehensive systematic study should be conducted to accompany the study on the shell morphology. This study focuses on the investigation of the intraspecific variation of biometrical data and compares the number and size classes of embryonic shells of $T$. granifera from three different locations in Indonesia. This preliminary studies is expected to provide supplementary data to complete the information status and identity of valid $T$. granifera.

\section{MATERIALS AND METHODS}

\section{Materials}

The study is based on materials from the collection of the Museum Zoologicum Bogoriense (MZB). All specimens were preserved in 70\% ethanol. For this study, we used 60 individuals of $T$. granifera from 3 different locations in Indonesia: 
Lempenge estuary, Dsn. Lempenge, Ds. Rempeg, district. Ganga, Kab. North Lombok, coll.date: 29 April 2014, coll: NR. Isnaningsih, n: 20 (MZB Gst. 17.551); river at Ds. Cijeruk, Pandeglang, Banten, coll.date: September 2015, coll: Heryanto, n: 20 (MZB Gst. 18.393); Bantimurung river, Maros, South Sulawesi, coll.date: July 13, 2006, coll: Aaron, n: 20 (MZB Gst. 15.698).

\section{Methods}

Specimens were investigated using a stereo microscope. Quantitative data were obtained by measuring the shell biometry which includes shell height (SH), shell width (SW), body whorls height $(\mathrm{BWH})$, aperture height $(\mathrm{AH})$, and aperture width (AW) (Fig. 1). These measurements were done using a caliper with $0.01 \mathrm{~mm}$ accuracy.

Total embryonic shells retained in each specimen were counted. Those data were obtained by dissecting the subhaemocoelic brood pouch in the anterior part. Embryonic shells were separated into four ontogeny stages (size classes): (a) 0.1-1 mm, (b) $1.1-2 \mathrm{~mm}$, (c) $2.1-3 \mathrm{~mm}$, (d) more than $3 \mathrm{~mm}$.

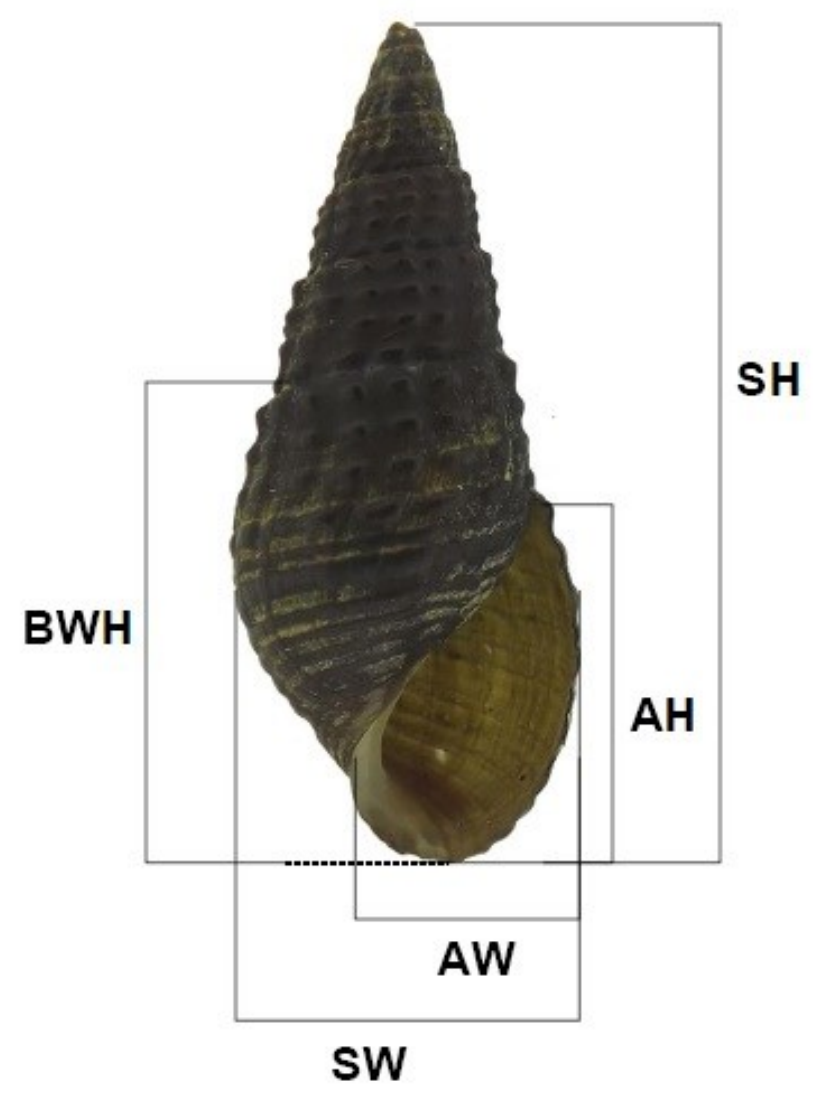

Figure 1. Parameters used to measure the shell dimensions (SH: shell height, SW: shell width, BWH: body whorls height, $\mathrm{AH}$ : aperture height and AW: aperture width). 
For SEM examination, the embryonic shells were soaked and washed with $20 \%$ clorox solution then were coated with gold at 5-8 $\mathrm{m} \AA$ for $5 \mathrm{~min}$. After coated, specimens were studied using a JEOL JSM5310LV scanning electron microscope (SEM) at an accelerating voltage of $20 \mathrm{kV}$.

\section{RESULTS}

Examination on 60 individuals of $T$. granifera are presented here, and some representative shells are shown (Fig. 2).

Thiaridae

Tarebia Adam H. \& A. Adam, 1854

Tarebia granifera Lamarck, 1822

\section{Taxonomy and systematics}

The first figure of $T$. granifera was published by Lamarck (1816) with the name Melania granifera without any description and location. Later Lamarck (1822) published following description "M. testa ouato-acutâ, striis Iransuersis crasslusculis granosis cincta, luteO'virescente; ullùno anfractu pentricoso; spirce ânfractibus planis; aperlurâ Alba ". In 1854, Adam \& Adam reassigned granifera to the genus Tarebia. A number of authors still refered to Lamarck (1819) and used the name Melania granifera (see Brot 1874, Rensch 1934), while others used the name Thiara granifera according to Adam \& Adam (1854), Benthem-Jutting (1937, 1941). Besides the two names, some other authors also used the name Melania lineata due to distinguishable dark lines coinciding with spiral ridges (Mousson 1848, Martens 1897). Based on this distinct characters, Rensch (1934) divided Melania granifera into two subspecies, namely M. granifera granifera and M. granifera lineata. Benthem-Jutting (1956) incorporated this species to the Melanoides granifera and wrote 19 synonyms. Furthermore, Glaubrecht (1996) returned the name to Tarebia granifera, so all the names that refered to the species Melania granifera described by Lamarck (1822) were considered as synonyms.

Shell - The shells of T. granifera has a medium shell size of $13.40 \mathrm{~mm}-32.15 \mathrm{~mm}$. Their shape are elongated conic and rather thick. There are $9-11$ spiral lines below the periphery. Axial lines are not visible. Spiral lines are as prominent as the axial lines so that granules are formed at the interceptions. The shell colour ranges from yellowish or light brown to dark brown or black. The apex is pointed and sometimes eroded. Shells of $T$. granifera usually have 6 to 8 whorls, with a high spire and regularly increasing size. The body whorl is evenly rounded and comprises about 0.5 

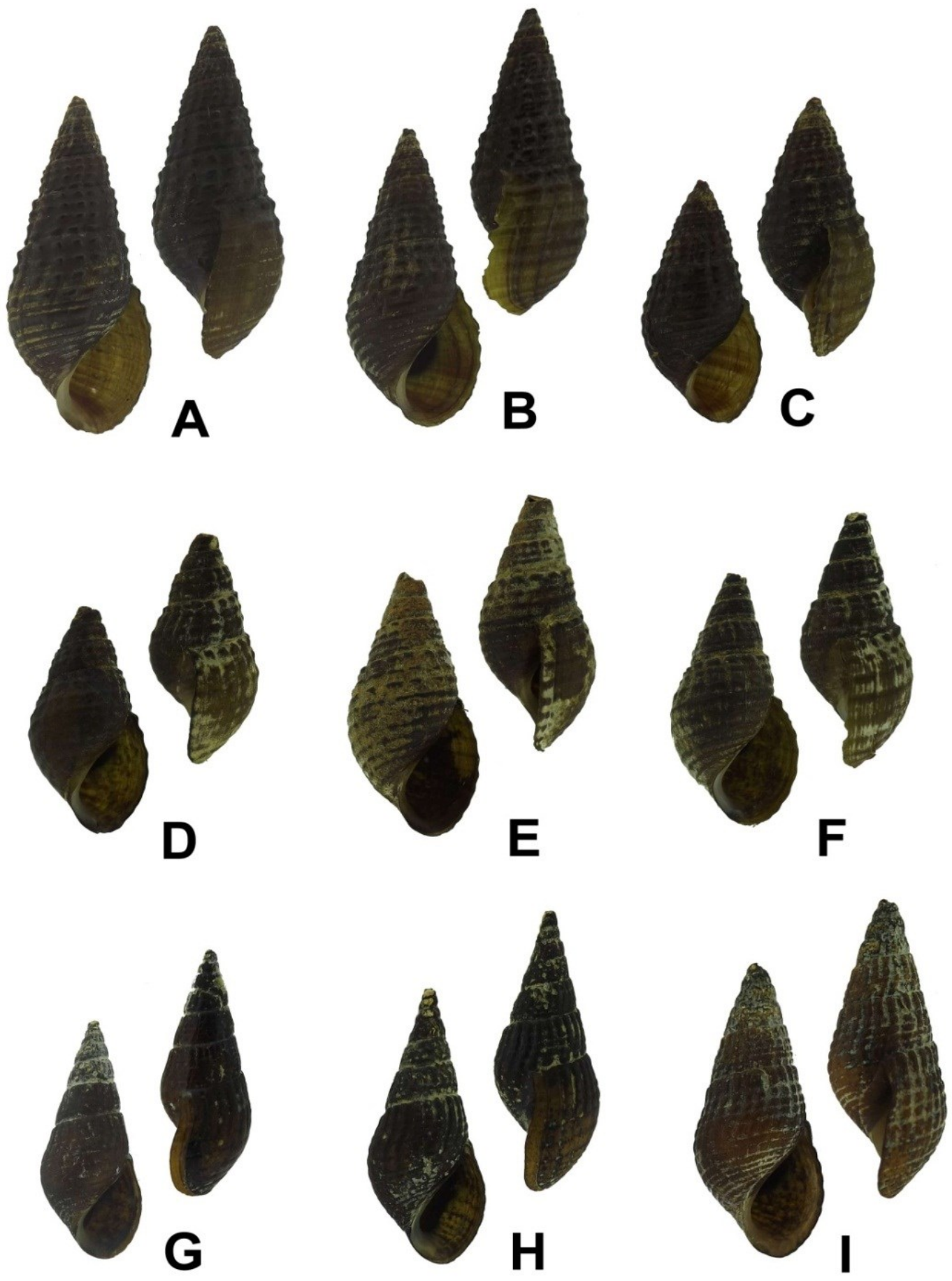

\section{$10 \mathrm{~mm}$}

Figure 2. Shells of T. granifera from Indonesia: A-C. MZB Gst. 17.551, River Lempenge, Dsn. Lempenge, Ds. Rempeg, district. Ganga, Kab. Lombok Utara; D-F. MZB Gst. 18.393, Ds. Cijeruk, Pandeglang, Banten; G-I. MZB Gst. 15.698, Bantimurung rivers, Maros, South Sulawesi. 
times of the total shell length. The suture of $T$. granifera is shallow. This species has oblique aperture with curved and uncontinuous apertural lip. The umbilicus is enclosed.

Operculum - The type of operculum is paucispiral, nucleus located in the lower edge of the operculum. There are eight rings sculpted on the outer surface of operculum.

Soft body-Animal is coiling in 3 whorls. The headfoot is black, while the mantle is white with black line in serrated marginal edge. The body has white colour. The snout is broad. Cephalic tentacle is about $2 \mathrm{~mm}$ in length. The location of eyes is at the base of tentacle. Ctenidium is about 7 times of osphradium.

Embryonic shell - The average of embryonic shell size is $0.90-1.04 \mathrm{~mm}$ in shell height with the maximum of shell height up to $5.85 \mathrm{~mm}$. Shell of embryo consists of 5 whorls. The apical whorl is smooth. Subsequence whorls decorated with strong ridge especially below the suture. Apical view of embryonic shell appears more wrinkle (Fig. 3).

The biometrical measurements showed that shell height varies in T. granifera from three different locations. The shell height of T. granifera from Lombok, Banten and Maros is 24.10 to $29.68 \mathrm{~mm}, 13.40$ to $25.37 \mathrm{~mm}$ and 10.01 to $32.15 \mathrm{~mm}$, respectively (Fig. 4). Although T. granifera of three locations showed high variation in the character of the shell height, but in general all specimens studied have the same shell shape index. This was indicated by the ratio of height and width of the shell (index SH / SW) which depicting similar pattern (Fig. 5).

From 20 individuals dissected, 17 individuals of $T$. granifera from Lombok retain embryonic shells (Fig. 6). Meanwhile, there are 9 individuals of T. granifera from Banten and 11 individuals from Maros that retain embryonic shells. The highest number of embryonic shells in brood pouch was found in T. granifera from Lombok. One individual from this location is able to retain 9 to 203 embryonic shells in their brood pouch, while 26 to 190 embryonic shells were found from one individual of $T$. granifera from Banten. Tarebia granifera from Maros bears $3-80$ embryonic shells (Fig. 7). The progeny develops in the maternal brood pouch. Because of that, the progeny in the brood pouch is found in increasing size classes. Most of embryonic shells are remained in brood pouch in $0.1-1.0 \mathrm{~mm}$ then followed by $1.1-2.0 \mathrm{~mm}$ in size (Fig. 8). A few were found reaching sizes of $2.1-3.0 \mathrm{~mm}$ and only 5 shells were found with more than $3 \mathrm{~mm}$ in $T$. granifera from Lombok. 
A

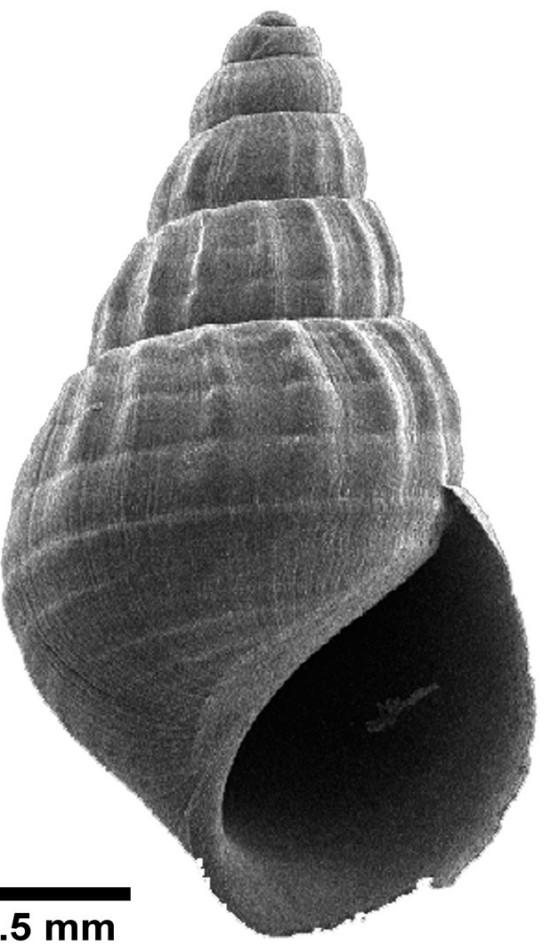

B

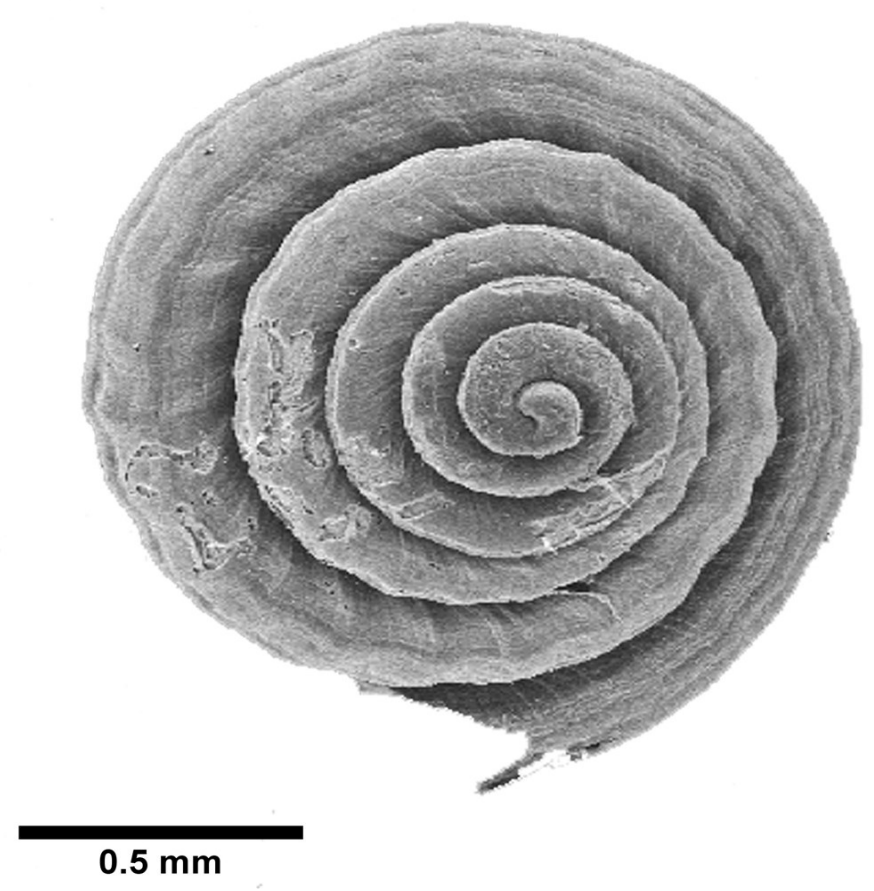

Figure 3. Embryonic shell of T. granifera from Ds. Cijeruk, Pandeglang, Banten (MZB Gst. 18.393), A. Lateral view: elongated conical, consists of 5-6 whorls, B. Apical view: apical whorl smooth, subsequent whorls sculptured with strong axial ribs especially below the suture. 


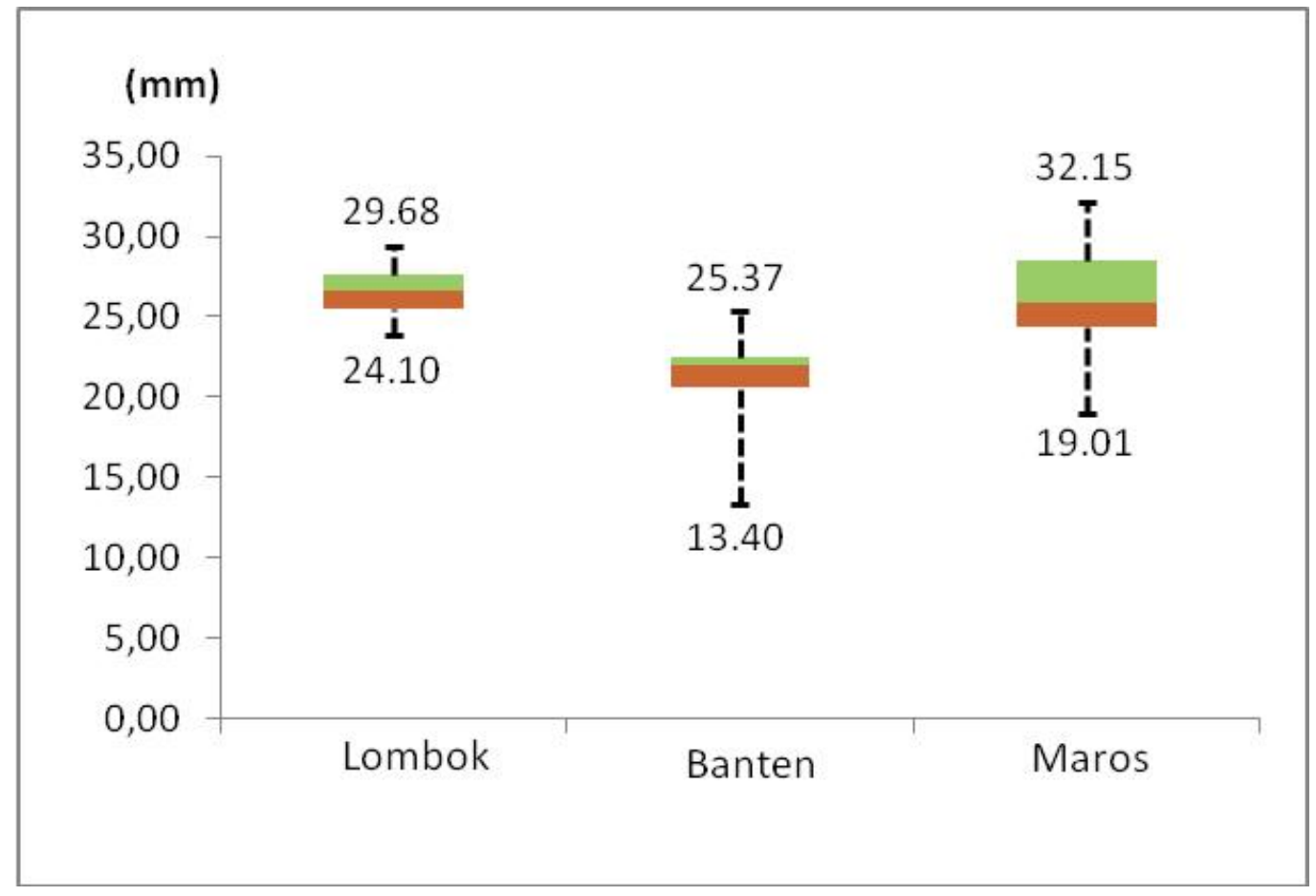

Figure 4. Boxplot of adult shell height of T. granifera from three different locations. Values below and above boxplot indicate minimum and maximum shell height, respectively.

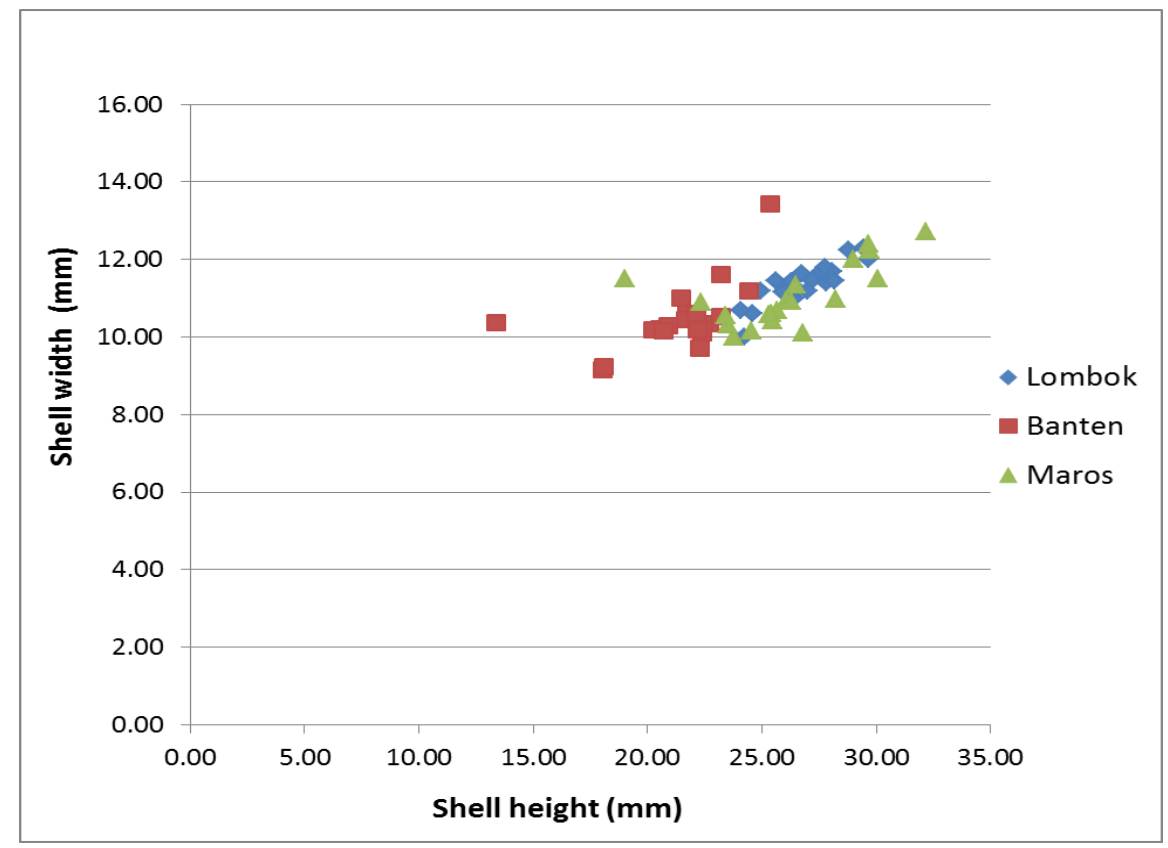

Figure 5. Scatter plot comparing shell height vs. shell width of $T$. granifera from three locations in Indonesia. 

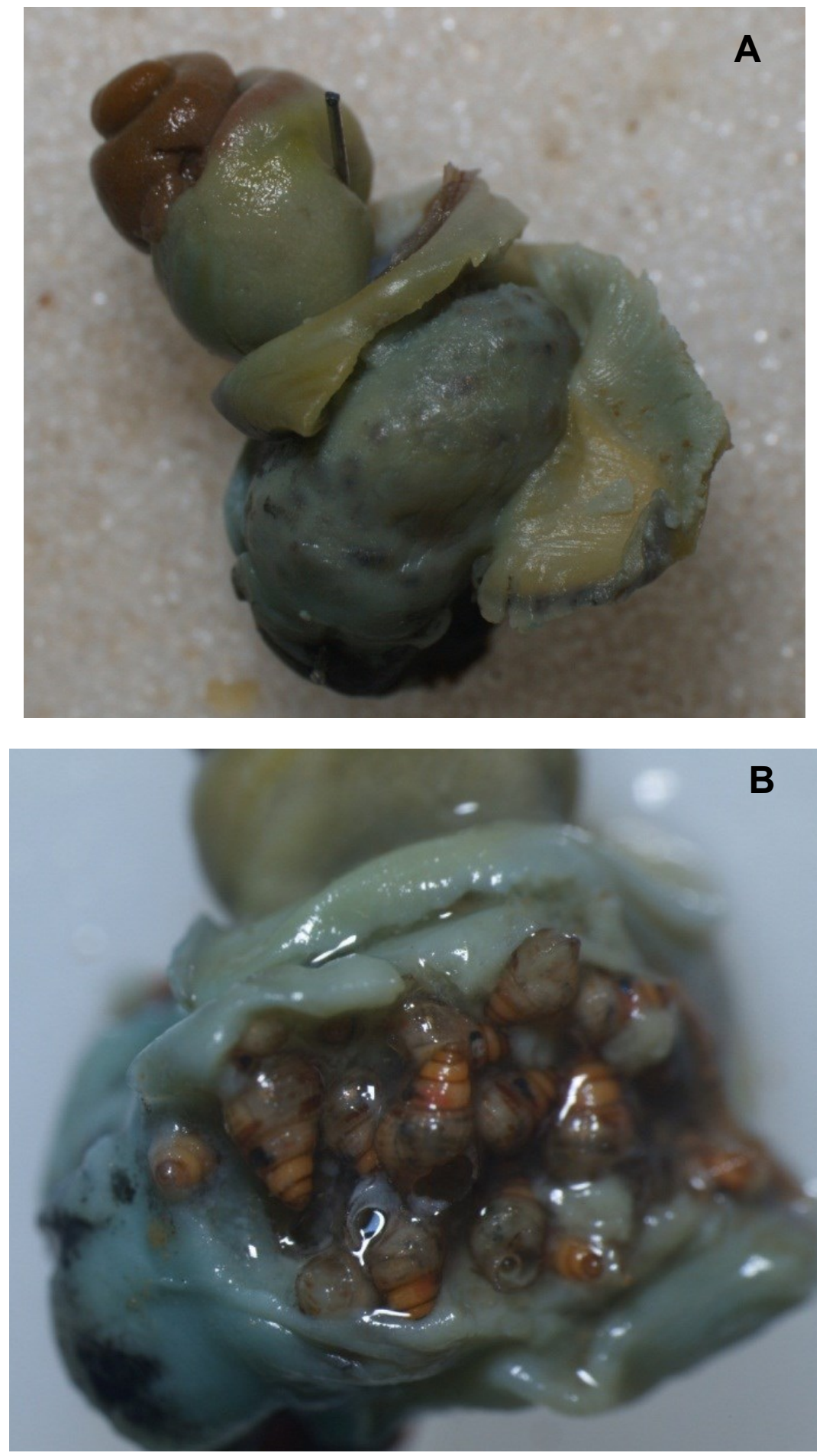

Figure 6. A. External view of the brood pouch located in neck part of the head and lying above the esophagus, B. Brood pouch filled with embryonic shells, one single individual could contain up to 203 embryos with the size ranging from 0.1 to $3 \mathrm{~mm}$. 


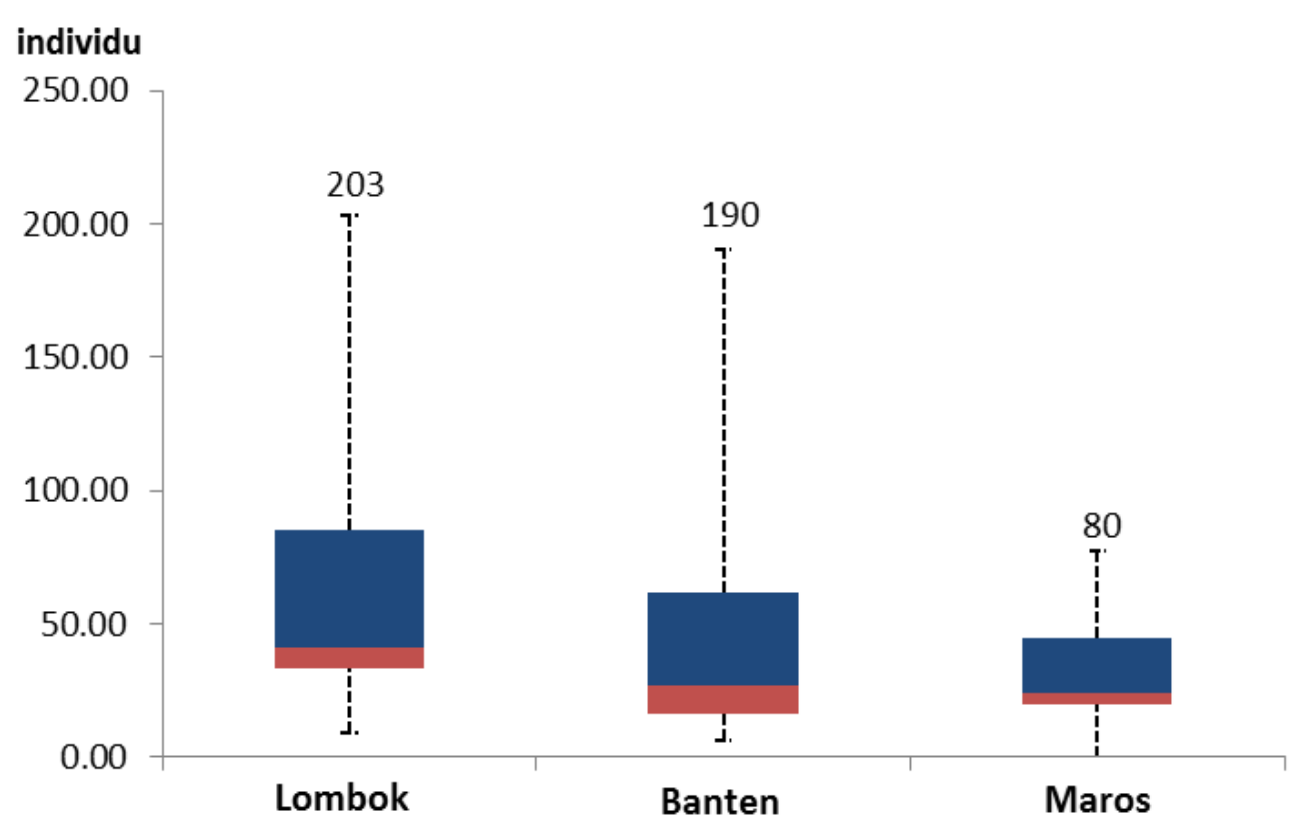

Figure 7. Boxplots of the total number of embryonic shells found in T. granifera from three different locations (Lombok, Banten and Maros). Values above error lines indicated the maximum number of embryonic shells in the brood pouch of one single female.

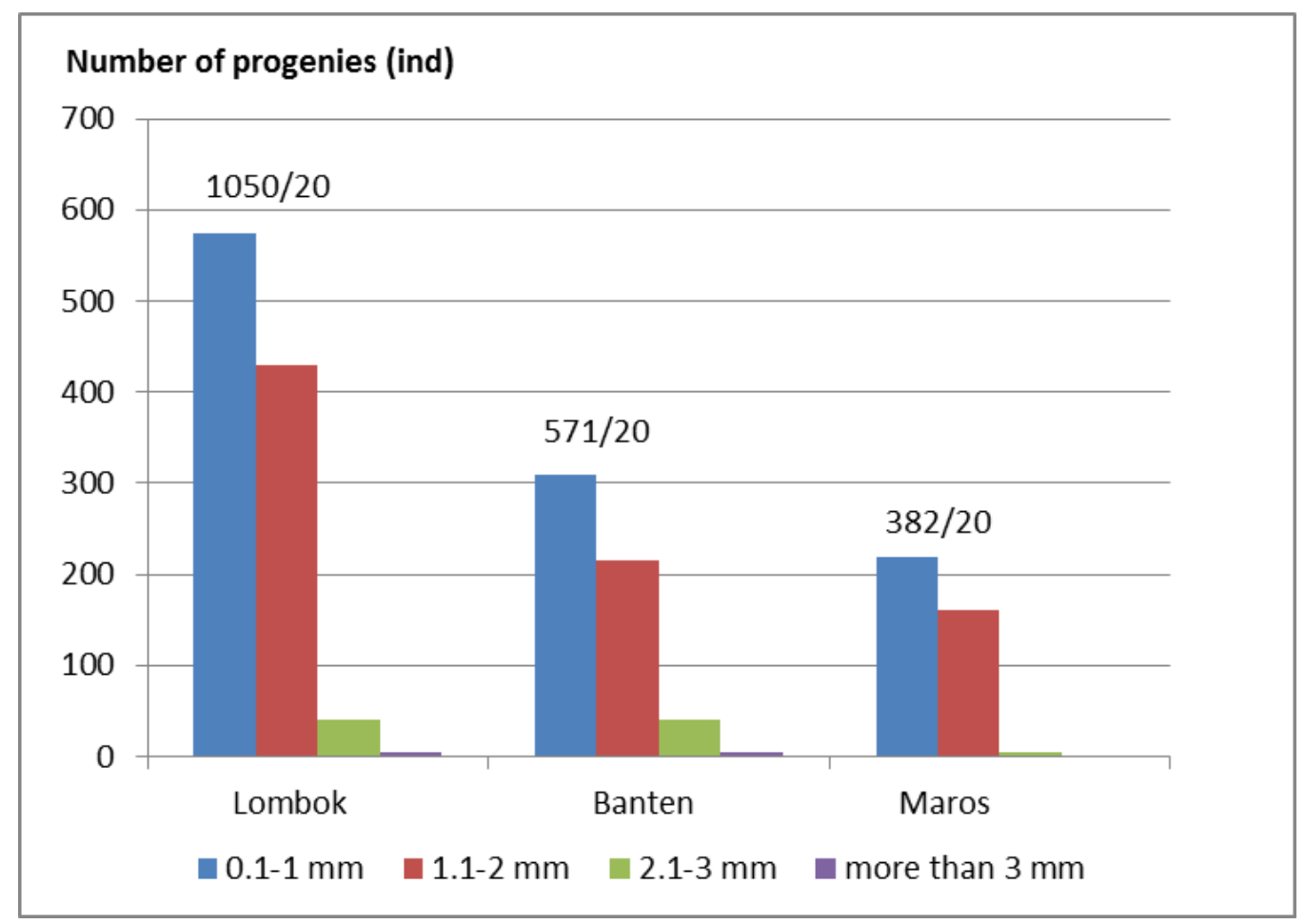

Figure 8. Number of embryonic shells of T. granifera found in four different ontogenetic stages ( 0.1 to higher than $3 \mathrm{~mm}$ ) from three different locations. Numbers of total embryonic shells from 20 individuals dissected are given above the respective columns. 


\section{DISCUSSION}

Measurement of shell height of $T$. granifera observed from three locations in Indonesia showed that the numbers are within the range of shell height previously reported which was 6 to $40 \mathrm{~mm}$ (Abbot 1952, Benthem-Jutting1956). The entire specimens of T. granifera from these three localities have the same shape that is elongate conic with the ratio of shell height and shell width are 1.29- $3.02 \mathrm{~mm}$ (see Fig. 4). Research on some populations of T. granifera from San Solomon Spring, West Texas showed that the maximum shell height of $T$. granifera from that location is $11.66 \mathrm{~mm}$ (Bradstret \& Rogowsky 2012). This maximum shell height from San Solomon Spring is much shorter than the shell height of $T$. granifera from Banten, Lombok, and Maros. Haase \& Bouchet (2006) explained that the dimension or size of shell actually shows spatial and temporal variations. The spatial and temporal variations follow the influence of different ecological conditions. Other intraspecies variations of $T$. granifera from Lombok, Banten and Maros are also seen in colour and ornaments of the shell, as well as spire height. The character of shell shape exhibited the similar trend. Likewise, the granules formed by the intersection of the axial and spiral lines show different characteristics. Specimens of $T$. granifera from Lombok and Banten have strong intersection between the two lines, therefore granules are formed clearly. In contrast, spiral lines on the body whorl of specimens from Maros are more dominant, so the granules are less clearly visible.

Tarebia granifera as a thiarid species has developed an extra uterine structure called subhaemocoelic brood pouch. The reproduction of $T$. granifera is parthenogenetic by nourishing the progenies in subhaemocoelic brood pouch. This structure is located at the back of the head and is elongated parallel to the gills. The progenies develop in the brood pouch before they are released into the habitat. The subhaemocoelic brood pouch is formed by an invagination of genital grove and the ovipositor organ which is also found in other oviparous gastropods that live in the sea and freshwater habitats (Glaubrecht 1999, 2006, Glaubrecht et al. 2009).

Ontogenetic studies conducted in T. granifera showed that specimens from Lombok produce the highest number of embryonic shells, reaching 203 embryonic shells from a single female which remained in brood pouch in various stages of $0.22 \mathrm{~mm}$ to about $5 \mathrm{~mm}$ in size. These results indicate that $T$. granifera has a fairly high reproductive capability compared to other thiarids such as Melanoides jugicostis and M. tuberculata. Melanoides jugicostis from Thailand bears $4-80$ embryonic shells in a brood pouch of single female, while M. tuberculata produces a maximum of 35 embryonic shells for each female (Dechruksa 2013). Research of Thiaridae from 
Australia conducted by Maaß \& Glaubrecht (2012) showed that Melasma onca produces more progeny compared to Thiara australis and Sermyla venustula. Furthermore, Maa $\beta$ \& Glaubrecht (2012) explained the tendency for each species to produce the number of progeny in different river systems (species-specific). Meanwhile, the differences in the number of embryonic shells from the same species as seen in the results indicate the influence of other factors, perhaps differences in season at the time of sampling.

The species identification should consider not only morphological characters but also ontogeny and reproductive aspect in order to obtain valid and accurate identification. Based on results above, it can be concluded that the specimens observed from Lombok, Maros and Banten are confirmed as valid $T$. granifera species.

\section{CONCLUSIONS}

Intraspecies variations of Tarebia granifera from Lombok, Banten and Maros are mainly seen in size and shell dimensions, colour and ornaments of the shell, as well as spire height. The character of shell shape exhibited the similar trend. The reproduction of $T$. granifera is parthenogenetic by nourishing the progenies in subhaemocoelic brood pouch. Ontogenetic studies conducted in $T$. granifera showed that specimens from Lombok produce the highest number of embryonic shells, reaching 203 embryonic shells from a single female which remained in brood pouch in various stages of $0.22 \mathrm{~mm}$ to about $5 \mathrm{~mm}$ in size.

\section{ACKNOWLEDGMENTS}

We would like to thank reviewers for suggesting and commenting on this manuscript. Many thanks also to Alfiah and Riena Prihandini (Laboratory of Malacology, Research Center for Biology) for their help in preparing the specimens. Thanks are due to Kartika Dewi for taking SEM photographs.

\section{REFERENCES}

Abbott, R.T. 1952. A study of an intermediate snail host (Thiara granifera) of the oriental lung fluke (Paragonimus). Proceeding of United States National Museum 102(3292): 71-116.

Appleton, C.C \& D. S. Nadasan 2002. First report of Tarebia granifera (Lamarck, 1816) (Gastropoda: Thiaridae) from Africa. Journal of Molluscan Studies 68: 399-402. 
Appleton, C.C., A.T. Forbes \& N.T. Demetriades 2009. The occurrence, bionomics and potential impacts of the invasive freshwater snail Tarebia granifera (Lamarck, 1822) (Gastropoda: Thiaridae) in South Africa. Zoologische Mededeelingen 83: 525-536.

Benthem-Jutting, W.S.S. van 1937. Non marine mollusca from fossil horizon in Java with special reference to the Trinil fauna. Zoologische Mededeelingen 20: 83-180.

Benthem-Jutting, W.S.S. van 1956. Systematic studies on the non-marine Mollusca of the Indo-Australian archipelago. V. Critical revision of the Javanese freshwater gastropods. Treubia 23: 259-477.

Benthem-Jutting, W.S.S. van 1959. Catalogue of the non-marine mollusca of Sumatra and of its satellite islands. Beaufortia 7: 41-191.

Benthem-Jutting, W.S.S. van 1963. Non-marine mollusca of west New Guinea, Part 1: Mollusca from fresh and brackish waters. Nova Guinea Zoology 20: 409-521.

Bradstreet, J \& D.L. Rogowski 2012. Native springsnails and the invasive red-rim Melania snail (Melanoides tuberculata), species habitat associations and life history investigations in the San Solomon Spring complex, Texas. Final Report the endangered species program grant no. tx e-121-r. Department of Natural Resources Management Texas Tech University: 81 pp.

Brot, A. 1874-1879. Die Melaniaceen (Melanidae) in Abbildungen nach der Natur mit Beschreibungen. In: Küster H.C. (ed), Systematisches Conchylien-Cabinet von Martini und Chemnitz. Nurnberg, Bauer \& Raspe, 1(24): 488 pp. 49 pls.

Cowie, R.H. 1995. Catalog and Bibliography of the Nonindigenous Nonmarine Snails and Slugs of the Hawaiian Islands. Bishop museum occasional papers 50: 66 p.

Dechruksa, W., D. Krailas \& M. Glaubrecht 2013. Evaluating the status and identity of "Melania' jugicostis Hanley \& Theobald, 1876 - an enigmatic thiarid gastropod in Thailand (Caenogastropoda, Cerithioidea). Zoosystematic and Evolution 89(2): 293-310.

Glaubrecht, M. 1999. Systematics and the evolution of viviparity in tropical freshwater gastropods (Cerithioidea: Thiaridae sensu lato): An overview. Courier Forschungs-Institut Senckenberg 215: 9196.

Glaubrecht, M. 2006. Independent evolution of reproductive modes in viviparous freshwater Cerithioidea (Gastropoda, Sorbeoconcha): A brief review. - Basteria, supplement 3: 32-38.

Haase, M \& P. Bouchet 2006. The radiation of hydrobioid gastropods (Caenogastropoda, Rissooidea) in ancient Lake Poso, Sulawesi. Hydrobiologia 556: 17-46.

Karatyev, A.Y., L.E. Burlakova, V.A. Karatyev, \& D.K. Padilla 2009. Introduction, spread, and impacts of exotic freshwater gastropods in Texas. Hydrobiologia 619: 181-194.

Lamarck, J.B.P.A. de M. de. 1816. Encyclopédie méthodique. Tableau Encyclopédique et méthodique des trois règnes de la nature. Vingt-troisième partie. Liste des objets representés dans les planches de cette livraison. V. Agasse, Paris, 391-488, 16 pls.

Lamarck, J.B.P.A. de M. de. 1819. Histoire naturelle des animaux sans vertèbres, présentant les caractères généraux et particuliers de ces animaux, leur distribution, leurs classes, leurs familles, leurs genres, et la citation des principales espèces qui s'y rapportent. Tome sixième, Paris: 343 pp.

Maaß, N \& M. Glaubrecht 2012. Comparing the reproductive biology of three "marsupial", eu-viviparous gastropods (Cerithioidea, Thiaridae) from drainages of Australia's monsoonal north. Zoosystematic and Evolution 88 (2): 293-315.

Morrison. J.P.E. 1954. The relationship of old and new world Melanians. Proceedings of the United States National Museum 103: 357-394. 
Mousson, A. 1849. Die Land und Süsswasser Mollusken von Java. Durck und Verlag von Friedrich Schulthess. Zürich.1-126, pls1-22.

Pointier, J.P., S. Samadi, P. Jarne and B. Delay 1998. Introduction and spread of Thiara granifera (Lamarck, 1822) in Martinique, French West Indies. Biodiversity and Conservation 7: 1277-1290.

Rensch, B. 1932. Die molluskenfauna der kleinen Sunda-Inseln Bali, Lombok, Sumbawa, Flores und Sumba. Zoologische Jahrbucher 63: 389-422.

Rensch, B. 1934. Suswassermollusken der deutschen limnologischen Sunda-Expedition. Archiv für Hydrobiologie, supplement 8: 203-254.

Wagner, P.J. 2001. Rate heterogeneity in shell character evolution among lophospiroid gastropods. Paleobiology 27(2): 290-310. 